（三重大学学芸学部化学教室, 津市) (昭和 31 年 11 月 10 日受理)

\title{
無機ペーパークロマトグラフ法に関する研究（第 $\mathbf{3}$ 報）
}

\section{第 I 族金属のペーパークロマトグラフィーについて}

山田省一

ペーパークロマトグラフィーによる第 I 族金属の分離 検出についてはすで多数の研究報告1222がされている。 著者もこれについて研究し第I 族金属のみか硝酸塩とし て与えられた場合の良好な展開戍を見出し，さらに進ん で第 I 族金属を塩化物として分離した場合にてれをク口 マトグラフ的に処理する良好な方法を見出したので報告 する。

\section{A. 第 I 族金属のみが硝酸塩として 与えられた場合}

\section{実験方法}

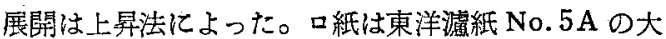
判を $2 \mathrm{~cm}$ 幅に切って使用。試料着点は液面より $5 \mathrm{~cm} の$ ところで試料採取量は $50 \mathrm{mg} / \mathrm{ml}$ のもの約 $2 \times 10^{-3} \mathrm{cc}_{\text {。 }}$ 展開温度は $20 \sim 25^{\circ} \mathrm{C}$ で同一展開においての温度差は $2^{\circ} \mathrm{C}$ 以内であった。展開所要時間は $3 \sim 4 \mathrm{hr} / 20 \mathrm{~cm}$ で ある。本実験においては活性成分として過塭素酸を使用 するので展開終了後アンモニア蒸気中で十分中和し，風 乾後硫化水素, 硫化アンモニウム等で昰色した。試料は 市販 1 級品を使用した。

\section{結果ならびに考察}

A-1. 過塩素酸を活性成分とする展開郕によるクロマ トグラム—活性成分としては 40〜 50\% 過塩素酸が最 も有効であり，有機成分としてはアセトン，メチルエチ

\section{第 1 表}

\begin{tabular}{|c|c|}
\hline (1) & アセトン $10+45 \%$ 過塩素酸 4 \\
\hline (2) & $"+" 1$ \\
\hline (3) & $" 10 \%$ \\
\hline (4) & メチルエチルケトン $10+45 \%$ 過塩素酸 4 \\
\hline (5) & フセトン $5+$ 酢酸エチュ5+45\%過程素酸 4 \\
\hline (6) & 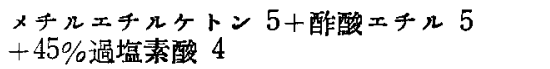 \\
\hline
\end{tabular}

（以上いずれる 容積組成）

1) 原沢，日化 72，295，352 (1951).

2) E. M. Lederer, "Chromatography" p. 324 (1954).

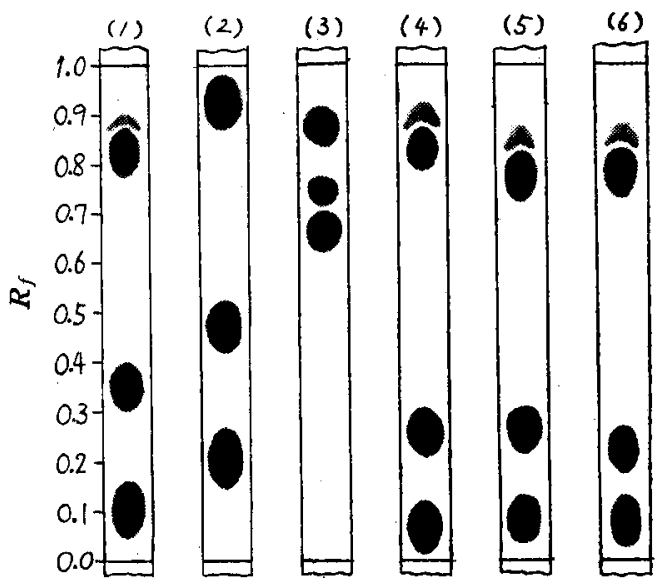

クロマトグラム上：水銀，中：銀，下：鉛 第 1 図

ルケトン，とくに前者がすぐれている。展開戍組成を第 1 表に示し，得られたクロマトグラムを第 1 四に示す。

(1)，(2)はアセトンに 45\% 過塩素酸を配合したも のであるがいずれも三金属は完全に分離している。ただ (1)，すなわち過塩素酸量の少ない場合は水銀のクロマ トグラムが2つの部分にわかれ上部はかなり薄いが，ち ようど萃をさしたような形になっている。過塩素酸量を 增すと（2)のように一つのクロマトグラムになる。(3) は過塩素酸濃度をうすくし，量を多くした場合であるが クロマトグラムは最も良好で水銀も単一な形をとってい る。ただし分離は前者程良好でない。水銀のクロマトク ラムの特異性についてはさらに検討を重衫る予定であ る。（4）はメチルエチルケトンを用いた場合である。 3 金属の分離は完全であるが水銀の状態が（1）よりる悪 い。(5)(6)は(1)(4)の有機溶媒の半容を䤏酸エチル で置きか光た場合であるがその影響ははとんど現われて いない。な执飽和 1 価アルコールは有機成分としてば不 適当である。

A-2. 過塩素酸濃度および量の变化と $R_{f}$ 值一アセ トンぶ最も良い有機成分となるのでとれに対する過塭素 酸の濃度わよび量を決定するため,つぎの実験を行った。 


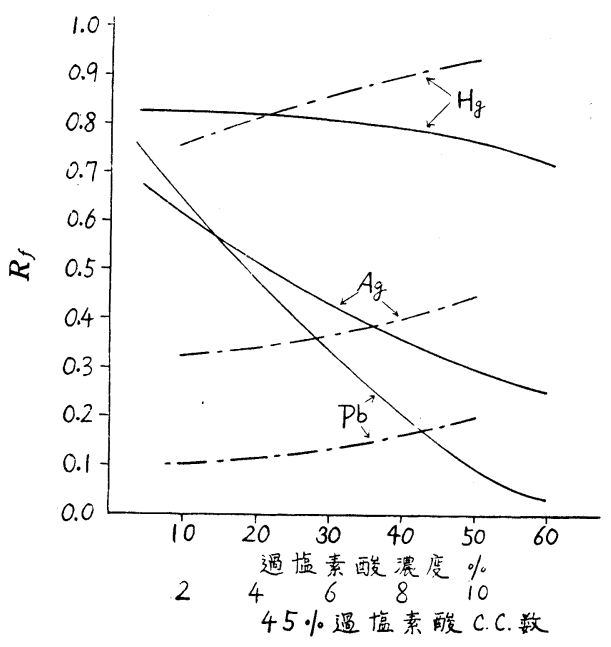

第 2 図

アセトン 10 容に各種濃度の過塩素酸 4 容を加えた展開 戍による三金属の $R_{f}$ 值を示すと第 2 図の実線のように なる。

水銀は濃度がかわってもあまり $R_{f}$ 值の変化を示さな い。鉛は最も濃度の影響をうけ銀はその中間にある。し たがって濃度をかえて行くと鉛と銀のクロマトグラムが 上下入れかわる。以上のととより 3 者の分離には $40 \%$ 以上の濃度が必要であるてとがわかる。しかし $60 \%$ に もなるとクロマトグラムが幾分長くなってくる。したが って過塩素酸濃度は 40～50\% が最適である。

つぎにアセトン 10 容に $45 \%$ 過塭素酸を 2 2 10 容加え た展開戍による $R_{f}$ 值を示すと同図破線のようになる。 すなわち量を変化させても $R_{f}$ 值にあまり大きな変化は なく,かつ三金属共大体平行的に变化する。30\%,20\%過 塩素酸を使用した場合もほとんど同じ傾向を示すのでこ の場合は量を増しても分離はよくならない。濃厚な過塩 素酸をあまり多量使用するてとは好ましくないので40\% 以上の場合は 2〜 6 容位が最適と思われる。ただ前述の ように水銀のクロマトグラムが少し悪いが検出限度には ほとんど影響しない。メチルエチルケトンもアセトンと 同じ傾向を示す。

A-3． 検出限度に関する実験一アセトン 10 容, $45 \%$ 過塩素酸 4 容を展開片とし試料採取量を $2 \times 10^{-3} \mathrm{cc}$ とし た場合の単独塩の検出限界濃度をあげると $\mathrm{Ag}^{+} 1 \mathrm{mg} /$ $\mathrm{m} l(2 \gamma), \quad \mathrm{Hg}_{2}{ }^{2}+3 \mathrm{mg} / \mathrm{ml}(6 \gamma), \quad \mathrm{Pb}^{2}+0.5 \mathrm{mg} / \mathrm{ml}$ (1r) である。混合塩についても 10～50 倍量の他金属 の存在において各金属の検出状態を検したのに単独塩の 時と変化はなかった。
A.-4. 展開溶媒の保存に関する実験——アセトン過塩 素酸系展開郕は数日の放置で黄色から赤褐色に着色して 来るが 20 日間の連続使用による実験では $R_{f}$ 值の変化 はほとんどなかった。なお口紙の着色もアンモニア蒸気 で消失し検出妨害はしない。

\section{B. 試料が第 I 族以外の金属も含み第 I 族 のみを塩化物として沈殿させた場合}

\section{実験方法}

（1）沈殿の溶解一一沈殿の溶郕としてロダンアンモ ニウム等が報告3)されているが著者は $40 \%$ ヨウ化カリ ウム溶液を用いた。紙上の沈殿は十分水を切り上記溶 液 $1 \mathrm{cc}$ をスポイドで数回くり返し注ぎ溶出させて試料 溶液をつくる。

（2）展開方法——形口紙による水平展開, 常法の 上昇法, 毛管による斑点分析等いずれでもよいが水平展 開が最もすぐれている。この場合は $1 \mathrm{~cm}$ 幅の切り込み を入れた口紙の中心部に試料を付し，ペトリー血を用い て展開させる。 $3 \mathrm{~cm}$ ぐらい展開させれば十分で所要時 間は 5 分以内である。上昇法の場合は試料は液面より 2 $\sim 3 \mathrm{~cm}$ のところに附し 7〜 $10 \mathrm{~cm}$ 展開させる。所要時 間は 10〜15 分である。斑点分析の場合は口紙上に試料 を付しキャピラリーを用いて溶媒をスポットの中心部よ り徐々に浸透させる。溶媒は $0.1 \mathrm{ml}$ あれば十分で 1 分 以内でよい。以上いずれの場合も口紙は No. $5 \mathrm{~A}$ を用 い試料採取量は $0.01 \mathrm{ml}$ である。展開に当りとくに注意 すべきことは口紙に試料を附したならば展開溶媒はあら かじめ用意して置き，風乾しないでただちに展開するて とである。展開終了後風乾して硫化アンモニウム, 多硫 化アンモニウムをスプレーして顕色する。クロマトグラ ムの保存には口紙を水洗しておかないと硫化銀が消失 し，なおヨウ化カリウムが分解されて着色したクロマト グラムができて来る。

\section{結果および考察}

B-1. 展開溶媒組成および生成クロマトグラム——展 開溶媒は酶酸エチル 10 容, $28 \%$ アンモニア 2 容に二相 が消失するまでアセトンを加える。 $20^{\circ} 〜 25^{\circ} \mathrm{C}$ において はアセトン 5 容を必要とする。得られたクロマトグラム を第 3 図（次頁）に示す。

三金属共完全に分離している。移動機構を考察するに $\mathrm{Hg}_{2}{ }^{2+}$ は $\mathrm{HgI}_{4}{ }^{2-}$ の形で存在し有機溶媒によくとけて溶 媒前線と共に進む。 $\mathrm{Ag}^{+}$はアンモニアの前線上にある ことから $\mathrm{AgI}_{3}{ }^{2-}$ がアンモニアにより分解され沈殿とな 3）鈴木，日化 76, 648 (1955). 
第 2 表 混合塩 $の$ 榆出状䔮

\begin{tabular}{|c|c|c|c|c|c|c|c|c|c|c|c|c|c|c|}
\hline \multicolumn{3}{|c|}{$\begin{array}{c}\text { 金属才ィ之濃度 } \\
(\mathrm{mg} / \mathrm{m} l)\end{array}$} & \multicolumn{3}{|c|}{$\begin{array}{c}\text { 採取した金属イオン量 } \\
(\mathrm{mg})\end{array}$} & \multicolumn{3}{|c|}{ イオン量の比 } & \multicolumn{2}{|r|}{ 検 } & 出 & \multicolumn{3}{|c|}{ 態 } \\
\hline \multirow[b]{2}{*}{$\mathrm{Ag}^{+}$} & \multirow[b]{2}{*}{$\mathrm{Hg}_{2}{ }^{2+}$} & \multirow[b]{2}{*}{$\mathrm{Pb}^{2+}$} & \multirow[b]{2}{*}{$\mathrm{Ag}^{+}$} & \multirow[b]{2}{*}{$\mathrm{Hg}_{2}{ }^{2+}$} & \multirow[b]{2}{*}{$\mathrm{Pb}^{2+}$} & \multirow{2}{*}{\multicolumn{3}{|c|}{$\mathrm{Ag}^{+}: \mathrm{Hg}_{2}{ }^{2+}: \mathrm{Pb}^{2+}$}} & 小 & & 形 & 工 & & 開 \\
\hline & & & & & & & & & $\mathrm{Ag}^{+}$ & $\mathrm{Hg}_{2}{ }^{2+}$ & $\mathrm{Pb}^{2+}$ & $\mathrm{Ag}^{+}$ & $\mathrm{Hg}_{2}{ }^{2+}$ & $\mathrm{Pb}^{2+}$ \\
\hline 0.2 & 0.5 & 5.0 & 0.2 & 0.5 & 5.0 . & 1 & $: 2$ & $5: 25$ & \pm & + & + & - & + & + \\
\hline 0.2 & 5.0 & 10.0 & 0.2 & 5.0 & 10.0 & 1 & $: 25$ & $: 50$ & + & + & + & - & + & + \\
\hline 0.2 & 10.0 & 5.0 & 0.2 & 10.0 & 5.0 & 1 & $: 50$ & $: 25$ & + & + & + & - & + & + \\
\hline 5.0 & 0.5 & 10.0 & 5.0 & 0.5 & 10.0 & 10 & $: 1$ & $: 20$ & + & + & + & + & - & + \\
\hline 10.0 & 0.5 & 5.0 & 10.0 & 0.5 & 5.0 & 20 & $: 1$ & $: 10$ & + & \pm & + & + & - & + \\
\hline 5.0 & 10.0 & 2.0 & 5.0 & 10.0 & 2.0 & 2.5 & $: 5$ & $: 1$ & + & + & - & + & + & - \\
\hline 10.0 & 5.0 & 2.0 & 10.0 & 5.0 & 2.0 & 5 & $: 2$ & $5: 1$ & + & + & - & + & + & - \\
\hline 50.0 & 25.0 & 5.0 & 50.0 & 25.0 & 5.0 & 10 & : 5 & $: 1$ & + & + & + & + & + & + \\
\hline 50.0 & 50.0 & 50.0 & 50.0 & 50.0 & 50.0 & 1 & $: 1$ & $: 1$ & + & + & + & + & + & + \\
\hline
\end{tabular}

$(+：$ 検出可能，士：検出不確実，一：检出不可能)

(b)
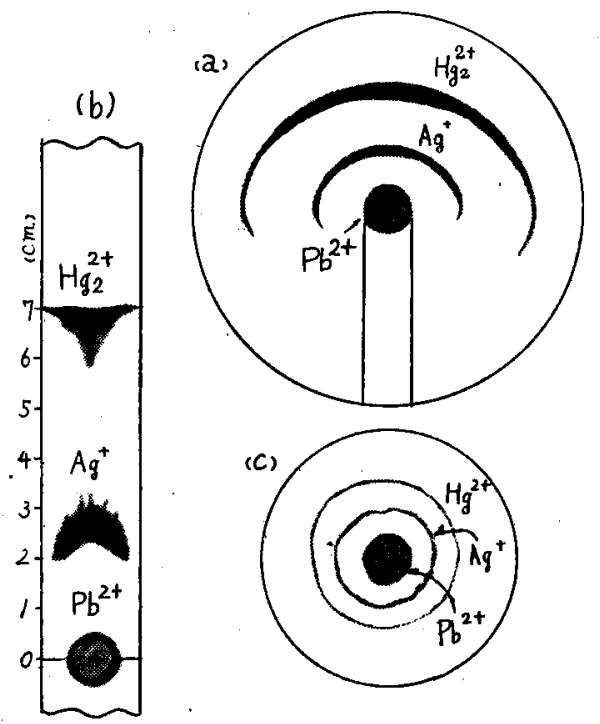

（a ）水平展開，（b ）：上界展開，（c）：斑点分析

第 3 図

るも過剩のアンモニアにとけて移動する。 $\mathrm{Pb}^{2+}$ は $\mathrm{PbI}_{3}-$ となっているがアンモニアのために分解されて $\mathrm{Pb}(\mathrm{OH})_{2}$ となり原置線上に止まる。試料附してから風乾すると アンモニアガスの吸収が遅れ $\mathrm{PbI}_{8}-$ が完全に分解され ない前に有機溶媒の前線通過となりてれに溶解して移動 するためクロマトグラムが流れ分離検出を悪くする。展 開溶媒は少量ずつ毎回新しくつくる方がよい。

B-2. 第 I 族金属塩化物より各金属イオンの検出限界 一各種濃度の単独イオン溶液 $1 \mathrm{~m} l$ を取り垭酸で沈殿 させてれを 40\% ヨウ化カリウム溶液にとかした試料溶 液 $7 \times 10^{-3} \mathrm{~m} l$ をとってスポットし, 展開終了後硫化ア
ンモニウムで検出しその状態で検出の可否を決定した。 それによると水平展開，上暑法展開いずれの場合におい ても $\mathrm{Ag}^{+}, \mathrm{Hg}_{2}{ }^{2+}, \mathrm{Pb}^{2+}$ はそれぞれ $1 \mathrm{ml}$ 当り $0.2 \mathrm{mg}$, $0.5 \mathrm{mg}, 2.0 \mathrm{mg}$ まで検出できた。

さらに混合塩については各種浱度の単独イオン溶液 1 $\mathrm{m} l$ ずつ計 $3 \mathrm{~m} l$ をとって混合し, 単独塭の場合と同し ようにして検出の可否を見た。結果を第 2 表に示す。

とれによって見ると水平展開の方がすぐれているとと がわかる。なお塭化物口過用口紙は No. 5A の円形の るのを使用した。

\section{C. 結 論}

本研究によりつぎのことを知った。

1）武料として第I 族金属のみが硝酸塭として与えら れた場合アセトン: 40〜50\% 過塩素酸=10:2〜6の展 開詴により三金属を完全に分離することができた。その 場合の各塩単独および混合塩溶液につき検出限度を検討 し，展開削の保存鹉験も行った。

2）武料が第I族以外の金属も含んでおり第I族のみ を塭化物として分離した場合の沈殹溶解剂として $40 \%$ ぐらいの, 濃厚なヨウ化カリウム溶液を用い，てれを口 紙上に注いで斌料溶液をつくうだ。展開刳として酶酸エ チル：28\%アンモニア：アセトン=10:2:5のものを 使用すれば非常に短時間にかつ各種の方法の展開で三金 属を完全に分離することができた。なおその場合単独お よび混合塭溶液につき検出状態を検討しだ。

終りにのぞみ本実骵に協力された学生前川 勉君に篤 く感謝する。

（昭和 30 年 11 月, 日本化学会東海支部大会講演） 